\title{
KAWASAN TEKNOLOGI PEMBELAJARAN
}

\author{
Nama Penyusun \\ Anang Pambudi, Emy Elma Wati, Luluk Masruroh, Melly Eka Tryse A, Siti Badriyah \\ Mellyagustin19@yahoo.com \\ Dosen Pengampu : M Barid Nizarudin
}

Pemahaman akan teknologi dalam konteks pendidikan dan pembelajaran kadang banyak di pengaruhi oleh bias konsep.dalam arti pemahaman terhadap teknologi itu sendiri kadang cenderung mengarah pada perangkat dan sistem otomatis yang sifatnya hardware, padahal pemahaman terhadap hakikat teknologi dalam konteks pendidikan dan pembalajaran justru diarahkan pada aplikasi dari teknologi sebagai 'ide' tentang rancangan bangunan dan hasil pikiranya. Demikian juga dalam telaah mengenai teknologi pembelajaran. Dimana di dalamnya terdapat pemahaman terhadap tekhnologi dan pembelajaran. Pembelajaran yang mengadopsi hasil pikir dan rancang bangunan suatu ide yang di wujudkan dalam produk tertentu dan memberikan kemudahan dalam pembelajaran, maka itulah salah satu pemahaman terhadap tekhnologi pembelajaran. Disamping pemahaman intinya yang lain bahwa "tekhnologi pembelajaran" itu send iri merupakan suatu tekhnologi, yaitu tekhnologi sebagai ide dan rancang bangun tentang bagaimana suatu proses pembeajaran bisa berkualitas melalui pengukuran efektivitas dan efisiensi, serta akselerasi pencapaian perubahan perilaku peserta didik, atau warga belajar.

Definisi tahun 1994, tekhnologi pembalajaran dirumuskan dengan berlandasan pada lima bidang garapan bagi tekhnologi pembalajaran, yaitu; desain, pengembangan, pemanfaatan, pengelolaan, dan penilaian. Tujuan dari uraian bab ini penulis pembaca mampu menganalisis setiap pergeseran paradigma definisi setiap kawasan teknologi pembelajaran. 


\section{Kawasan Teknologi Pe mbelajaran}

\section{A. Kawasan Desain}

Desain adalah proses untuk menentukan kondisi belajar. Tujan desain ialah untuk menciptakan strategi sdan produk dalam tingkat makro, seperti progam dan kurikulum dan pada tingkat mikro, seperti pembelajaran dan modul.

1. Deskripsi Kawasan

Kawasan desain paling tidak meliputi empat cakupan utama dari teori dan praktik. Cangkupan ini dapat diidentifikasi karena masuk dalam lingkup pengembangan penelitian dan teori. Kawasan desain meliputi studi mengenai sistem pembalajaran, desain pesan, strategi pembelajaran,dan karakteristik pembelajaran. Definisi dan deskripsi dari masing daerah adalah sebagai berikut.

2. Desain Sistem Pembelajaran

Desain sistem pembelajaran (DSI) adalah prosedur yang terorganisasi yang meliputi langkah-langkah penganalisan, perancangan, pengembangan, pengaplikasian, dan penilaian pembelajaran. Kata "desain" mempunyai pengertian tingkat makro maupun mikro karena menunjukan pada pendekaatan sistem maupun langkah lamgkah dalam pendekatan sistem. Setiap langkah mempunyai landasan teori dan praktek sendiri, penganalisaan adalah proses perumusan apa yang akan di pelajari. Perancangan adalah proses penjabaran bagaimana cara hal tersebut akan di pelajari. Pengembangan adalah proses penulisan dan pembuatan atau produksi bahan bahan pembelajaran. Pelaksanaan adalah pemanfaatan bahan atau strategi yang bersangkutan, dan penilaian adalah proses penentuan ketepatan pembelajaran. DSI biasanya merupakan suatu prosedur linier dan interaktif yang menuntut kecermatan dan kemantapan. Karakteristikdari proses ini ialah bahwa semua langkah harus tuntas agar dapat berfungsi sebagai alat untuk saling mengontrol.Dalam DSI,proses sama pentingnya dengan produk sebab kepercayaan atas produk berlandaskan pada proses.

\section{Desain Pesan}

Desain pesan meliputi perencanaan untuk merakayasa bentuk fisik dari pesan (Grabowski,1991:20G). Hal tersebut mencakup prinsip-prinsip perhatian, persepsi, dan daya serap yang mengatur pengirim dan penerima, fleming and levie (1993) membatasi pesan pada pola pola isyarat atau simbol yang memodifikasi perilaku kognitif, afektif, dan psikomotor. Desain pesan berurusan dengan tingkat paling mikro melalui unik unik kecil seperti bahan visual,urutan, halaman,dan layar secara 
terpisah. Karakteristik lain dari desain pesan ialah bahwa desain harus bersifat spesifik, baik terhadap mendianya maupun tugas belajarnya. Hal ini mengandung arti bahwa prinsip prinsip desain pesan akan berbeda bergantung pada apakah medianya bersifat statis, dinamis, atau kombinasi dari keduanya (misalnya, suatu potret, film, atau graft komputer) juga apakah tugas tersebut meliputi pembentukan konsep atau sikap, pengembangan ketrampilan, atau strategi belajar, atau hafalan.(Fleming,1987; Fleming dan levie,1993).

4. Strategi Pembelajaran

Strategi pembelajaran adalah spesifikasi untuk menyeleksi serta mengurutkan peristiwa belajar atau kegiatan pembelajaran dalam suatu pelajaran. Ada dua strategi yaitu strategi mikro dan strategi makro. Strategi mikro ini merupakan metode dasar dalam mengorganisasikan pembelajaran kedalam suatu gagasan tunggal antara lain seperti sebuah konsep, prinsip yang tunggal, dansebagainya. Hal tersebut mencakup komponen strategi seperti definisi, contoh, latihan dan bentuk sajian lain. Strategi makro adalah metode dasar untuk mengorganisasikan aspek pembelajaran yang berhubungan dengan gagasan lebih dari satu seperti mengumpulkan, membuat sintesis, dan membuat ringkasan (mem-preview dan merevisi) gagasan - gagasan yang diajarkan. (Sari \& Wajdi, 2017)

5. Karakteristik Pembelajar

Karakteristik pembelajaran adalah segi-segi latar belakang pengalaman pembelajar yang berpengaruh terhadap efektivitas proses belajarnya. Penelitian mengenai karakteristik pembelajaran sering tumpang tindih dengan penelitian strategi belajar, akan tetapi hal itu akan dilakukan dengan tujuan yang berbeda yaitu untuk menjelaskan segi - segi latar belakang pembelajaran yang perlu yang perlu di perhitungkan dalam desain. Lingkup strategi pembelajaran menggunakan tentang penelitian tentang motivasi untuk menentukan desain komponen pembelajaran. Lingkup karakteristik pembelajaran menggunakan penelitian tentang motivasi untuk mengidentifikasi variabel-variabel yang harus diperhitungkan dan untuk menentukan bagaimana caranya hal-hal tersebut harus diperhitungkan.

6. Kecenderungan dan Permasalahan

Kecenderungan dan permasalahan dalam kawasan desain berpusat pada penggunaan desain sistem pembelajaran yang tradisional, aplikasi teori belajar dalam desain, dan pengaruh dalam teknologi baru pada proses penyusunan desain. Walaupun orang sependapat bahwa pendekatan sistematis yang lebih tradisional 
terhadap desain tradisional masih banyak berarti, beberapa orang meragukan keunggulan model-model DSP, dan kecenderungan untuk menggunakan dalam cara linier dan tidak fleksibel. Mungkin kecenderungan yang lebih mendasar adalah diterimanya pendekatan-pendekatan alternative terhadap desain.

Apapun orientasi teoritis atau filosofis mereka, para desainer akan terpengaruh oleh perkembangan teknologi yang cepat yang membuka ajang baru bagi menyampaikan pembelajaran, disamping dari segi otomatisasi bagian-bagian proses desain itu sendiri. Sebagai alternative penyampaian, teknologi ini bukan saja memungkinkan visualisasi yang lebih efektif, tapi juga akses yang cepat terhadap informasi, kemampuan menghubungkan informasi, desain yang lebih mudah beradaptasi dan lebih interaktif dan cara belajar yang tidak bersifat formal (kannafun, 1992).

Sebagai alat otomatisasi desain, teknologi baru ini membuka kemungkinan bagi desainer untuk menggunakan aturan-aturan yang lebih terperinci dalam pemilihan strategi pembelajaran, melaksanakan pelatihan "saat diperlukan ", dan secara efisien dapat menanggapi harapan dan persyaratan dari organisasi mereka ( Dick, 1993 ). Semua kecenderungan ini merupakan reaksi terhadap permasalahan dan berpengaruh terhadap asas-asas desan pembelajaran ( Richey, 1993a ; Seels, 1993a ) .

\section{B. Kawasan Pengembangan}

Proses penerjemahan spesifikasi desain kedalam bentuk fisik. Mencakup banyak variasi teknologi. Kawasan pengembangan meliputi :

\section{Teknologi Cetak}

Cara memproduksi atau menyampaikan bahan - bahancontonyaseperti bukubuku dan bahan visual yang statis, terutama melalui proses pencetakan mekanis atau fotografis. Bahan cetak dan bahan visual menggunakanteknologi yang paling dasar dan membekas. Teknologi ini menjadi dasar untuk pengembangan dan pemanfaatan dari kebanyakan bahan pembelajaran lain.

\section{Teknologi Audiovisual}

Teknologi audiovisual merupakan cara memproduksi dan menyampaikan bahan dengan menggunakan peralatan mekanis dan elektronis untuk menyajikan pesan audio dan visual. Teknologi AV dinilai lebih aktif karena sifatnya memerlukan indra pendengaran dan penglihatan peserta didik. Pembelajaran audiovisual dapat dikenal dengan mudah karena menggunakan perangkat keras 
didalam proses pengajaran. Peralatan audiovisual memungkinkan pemroyeksian gambar hidup, pemutaran kembali suara, dan penayangan visual yang berukuran besar.

\section{Teknologi Berbasis Komputer}

Teknologi ini merupakan cara memproduksi dan menyampaikan bahan dengan menggunakan perangkat yang bersumber mikroprosesor. Teknologi berbasis computer dibedakan dengan teknologi lain karena menyimpan informasi secara elektronis dalam bentuk digital, bukannya sebagai bahan cetak atau visual.

4. Teknologi Terpadu

Teknologi terpadu adalah cara untuk memproduksi dan menyampaikan bahan dengan perpaduan dengan beberapa jenis media yang dihubungan dengan server komputer.

\section{Kawasan Pemanfaatan}

Pemanfaatan adalah Aktifitas menggunakan proses dan sumber untuk belajar. Pemanfaatan menuntut adanya penggunaan, deseminasi, difusi, implementasi, dan pelembagaan yang sistematis. Hal tersebut dihambat oleh kebijakan dan peraturan. Fungsi pemanfaatan penting karena fungsi ini memperjelas hubungan pembelajar dengan bahan atau sistem pembelajaran. Kawasan pemanfaatan meliputi:

1. Pemanfaatan Media

Penggunaan yang sistematis dari sumber belajar. Proses pemanfaatan ini merupakan proses pengambilan keputusan berdasarkan spesifikasi desain pembelajaran. Misalnya, bagaimana suatu film diperkenalkan atau ditindak lanjuti dan dipolakan sesuai dengan bentuk belajar yang diinginkan.

2. Difusi Inovasi

Difusi inovasi merupakan proses berkomunikasi melalui strategi yang terencana dengan tujuan untuk diadopsi. Diharapkan dengan difusi inovasi akan dicapai perubahan yang diinginkan. Tahap pertama dalam proses ini ialah membangkitkan kesadaran melalui desiminasi informasi. Proses tersebut meliputi tahap-tahap seperti kesadaran, minat, percobaan dan adopsi.

3. Kebijakan dan Regulasi

Sebagai aturan dan tindakan nyata dari pengguna atau dari pembuat keputusan untuk menerima inovasi(dalam teknologi pembelajaran).

\section{Kawasan Pengelolaan}


Pengelolaan meliputi pengelolaan Teknologi Pembelajaran melalui perencanaan, pengorganisasian, pengoordinasian, dan supervisi. Pengelolaan biasanya merupakan hasil dari penerapan suatu sistem nilai. Pengelolaan meliputi:

1. Pengelolaan proyek, yaitu mempin pekerjaan yang harus selesai dalam kurun waktu tertentu. Sebagai contoh, proyek pengembangan suatu produk pembelajaran tertentu.

2. Pengelolaan sumber mencakup perencanaan, pemantauan, dan pengendalian sistem pendukung dan pelayanan sumber. Pengelolaan sumber sangatlah penting karena mengatur pengendalian akses. Pengertian sumber dapat mencakup personel, keuangan, bahan baku, waktu, fasilitas, dan sumber pembelajaran.

3. Pengelolaan sumber penyampaian, pengelolaan ini meliputi perencanaan, pemantauan, pengendalian“ cara bagaimana distribusi bahan pembelajaran diorganisasikan. Hal tersebut merupakan suatu gabungan medium dan cara pengunaan yang dipakai menyajikan informasi pembelajaran kepada pembelajar.

4. Pengelolaan informasi, yaitu bagaimana informasi dapat diterima, dan dapat menghasilkan perubahan atas kurikulum dan desain pembelajaran.

\section{E. Kawasan Penilaian}

Proses penentuan memadai tidaknya pembelajaran dan belajar. Penilaian adalah kegiatan untuk mengkaji serta memperbaiki suatu produk atau program. Kawasan penilaian terdiri dari :

1. Analisis masalah

Mencakup cara penentuan sifat dan parameter masalah dengan menggunakan strategi pengumpulan informasi dan pengambilan keputusan.

2. Pengukuran acuan patokan (criteria-refenced test)

Teknik-teknik untuk menentukan kemampuan pembelajar menguasai materi yang telah ditentukan sebelumnya.

3. Penilaian formatif

Penilaian formatif mengandalkan pada kajian teknis dan tutorial, uji coba dalam kelompok kecil atau besar, metiode pengumpulan datanya bersifat informal bermanfaat untuk pengembangan program dan produk pembelajaran

4. Penilaian sumatif

Penilaian sumatif berkaitan dengan pengumpulan informasi tentang kecukupan untuk pengambilan keputusan dalam hal pemanfaatan. Penilaian sumatif sering menggunakan study kelompok komparatif dalam desain kuasi eksperimental. 


\section{F. Kawasan Perlengkapan}

Kawasan ini mungkin merupakan hal yang paling pelik dan berliku-liku dibandingkan domain lain dalam Teknologi Pembelajaran. Dalam domain inilah digeluti segala hal tentang pendaya gunaan media instruksional yang baik untuk mencapai tujuan pengajaran, termasuk urusan pelembagaan serta kebijakan dan peraturan yang dapat mendukung atau sebaliknya menghambat. Domain perlengkapan merupakan bagian usaha mendayagunakan proses dan sumber belajar untuk mencapai tujuan pengajaran.

\section{G. Kawasan Evaluasi}

Evaluasi merupakan proses menentukan kesesuaian antara materi pelajaran dan proses belajar. Evaluasi dimulai dengan analisis problem yang merupakan langkah awal penting dalam pengembangan dan evaluasi isi pelajaran karena tujuan dan kendalanya diklarifikasi selama langkah ini dilaksanakan. 
References

Abdulhak, Ishak.2015.Teknologi Pendidikan Cet 2.Bandung: PT Remaja Rosdakarya

Seels, D Barbara, Rita C Richey.1994.Instructional Technology: The Definition and Domains of the Field.Washington:AECT

Duffy, Judy Lever, dkk.2003. Teaching and Learning with Technologi.Boston:Allyn and Bacon Publishing

Dick, Walter.Reiser, Robert A.,1989.Palnning Effective Instruction.New Jersey: Englewood Cliffs

Sari, D. E., \& Wajdi, M. B. N. (2017). The Effectiveness Of The Method of GI With Electronic Workbench Study To Improve Activities and Results Student. Educatio : Journal of Education, 2(1), 136-150. Retrieved from http://www.ejournal.staimnglawak.ac.id/index.php/educatio/article/view/22 